Diabetologia 11, 159-164 (1975)

c) by Springer-Verlag 1975

\title{
Cell Size and the Antilipolytic Effect of Insulin in Human Subcutaneous Adipose Tissue
}

\author{
J. Östman, L. Backman and D. Hallberg \\ Dept. of Medicine, Huddinge University Hospital, and the Departments of Surgery and Surgical Research, Karolinska Hospital, \\ Stockholm, Sweden \\ Received: Juni 7, 1974, and in revised form: January 30, 1975
}

\begin{abstract}
Summary. Lipolysis was studied in subcutaneous adipose tissue removed under local or general anaesthesia from subjects with marked difference in body weight and from obese subjects before and after intestinal shunt operations. The release of glycerol was measured in sections of adipose tissue incubated for two hours in bicarbonate buffer containing 4 per cent bovine albumin with no glucose added. The larger fat cells were more insulin sensitive than the smaller. A positive relationship was observed between the fat cell size
\end{abstract}

and the antilipolytic effect of insulin $(100 \mu \mathrm{U} / \mathrm{ml})$. Insulin had no significant effect on the lipolytic effect of the catecholamines, when this is calculated as the increment in the glycerol release above the basal.

Key words: Release of glycerol, adipose tissue, cell size, insulin, isopropyl-noradrenaline, noradrenaline, obesity, jejunoileostomy.
It has been shown by others that the stimulating effects of insulin on the oxidation of glucose to $\mathrm{CO}_{2}$ [7, 19] and on the synthesis of lipids [21] are less pronounced in large human adipocytes than in the small fat cells. Since we have shown [26] that the adipokinetic effect of various agents was related to the size of the human fat cells, it seemed important to investigate whether or not the antilipolytic effect of insulin was also cell-size dependent.

To study this, subcutaneous adipose tissue was removed from patients with normal body weight and from obese patients who were submitted to intestinal shunt operations. The release of glycerol from segments of adipose tissue was determined under basal conditions, e.g. when incubated in glucose-free albumin containing bicarbonate buffer, and when the lipolysis was accelerated by the addition of either noradrenaline (NA) or isopropyl-noradrenaline (ISNA). The antilipolytic effect of insulin $(100 \mu \mathrm{U} / \mathrm{ml})$ was analyzed with regard to the size of the adipocytes, which was determined histiometrically [20]. In a number of obese patients operated upon because of massive obesity a second biopsy was performed several months later, when significant body weight reduction and, most likely, a decrease in the fat cell size had occurred [11].

\section{Materials and Methods}

Segments of subcutaneous adipose tissue were removed from 12 obese patients submitted to intestinal shunt operation and from six patients submitted to cholecystectomy. Biopsy specimens of subcutaneous adipose tissue were removed during local anaesthesia
Table 1. Clinical data of the patients included in the study

\begin{tabular}{|c|c|c|c|c|c|}
\hline Pat. & Age & Sex & & xt. & Type of operation \\
\hline no. & & & $\mathrm{kg}$ & $\%$-ideal & \\
\hline 1 & 26 & $\mathrm{~F}$ & 164 & 241 & \\
\hline 2 & 28 & $\mathrm{~F}$ & 127 & 202 & Jejunoileostomy + pre- \\
\hline 3 & 35 & F & 117 & 192 & operative and postope- \\
\hline 4 & 37 & M & 175 & 262 & rative biopsies \\
\hline 5 & 44 & $\mathrm{~F}$ & 172 & 272 & \\
\hline 6 & 45 & $\mathrm{~F}$ & 118 & 198 & Jejunoileostomy + pre- \\
\hline 7 & 48 & M & 146 & 192 & operative biopsy \\
\hline 8 & 24 & $\mathrm{~F}$ & 102 & 194 & \\
\hline 9 & 35 & $\mathbf{F}$ & 105 & 184 & \\
\hline 10 & 35 & $\mathbf{M}$ & 117 & 178 & Biopsy \\
\hline 11 & 48 & F & 116 & 178 & \\
\hline 12 & 55 & $\mathrm{~F}$ & 95 & 163 & \\
\hline 13 & 19 & $\mathrm{~F}$ & 106 & 179 & \\
\hline 14 & 24 & $\mathrm{~F}$ & 90 & 134 & \\
\hline 15 & 44 & $\mathrm{~F}$ & 48 & 80 & Cholecystectomy + pre- \\
\hline 16 & 48 & M & 87 & 124 & operative biopsy \\
\hline 17 & 49 & M & 90 & 134 & \\
\hline 18 & 49 & M & 72 & 104 & \\
\hline
\end{tabular}

from 10 obese patients. From five of these patients adipose tissue had been removed during the intestinal shunt operation performed several months earlier. Clinical data and the type of surgical procedure are given in Table 1 . The ideal body weight was obtained from the tables computed by the Metropolitan Life Insurance Company [23]. No subject had diabetes mellitus. All had a normal fasting blood glucose level. The slight decrease in glucose tolerance in three very obese subjects before the intestinal shunt operation was not synonymous with diabetes mellitus. The procedures were performed under general anaesthesia, after an overnight fast. All patients were intubated and 
given muscle relaxants (succinyl-choline). Anaesthesia was induced with the short acting barbiturate, Narko$\mathrm{tal}^{\circledR}$ (Astra, Södertälje, Sweden) and continued with Halothane ${ }^{\circledR}$ (Hoechst, Frankfurt, West Germany). Only saline was given intravenously until the biopsy was removed. This was done early during the operation. The abdominal incisions were made transversly from the umbilicus to the right. The jejuno-ileostomy was performed as an end-to-end anastomosis with an ileocaecostomy end-to-side (the principle described by Buchwald and Varco [2]).

The postoperative biopsies were taken from an abdominal area symmetrically positioned with the first biopsy to the left of the umbilicus. A local anaesthetic was used (Xylocain ${ }^{\circledR}$ 1\%, Astra, Södertälje, Sweden) and injected intradermally as described in detail elsewhere [1]. The patients were fasted overnight.

\section{Incubation Procedure}

Immediately after removal, the adipose tissue was transferred into Krebs-Henseleit bicarbonate albumin solution, kept at $37^{\circ} \mathrm{C}$, for about 10 minutes. The tissues were divided into sections weighing approximately $50 \mathrm{mg}$ and preincubated for $30 \mathrm{~min}$ in KrebsHenseleit bicarbonate buffer containing $4 \%(\mathrm{w} / \mathrm{v})$ bovine serum albumin (Armour Pharm Co., Eastbourne, U.K.; Lot number R No 970) and glucose $(5 \mathrm{mM})$. About $50 \mathrm{mg}$ of adipose tissue was incubated in $1 \mathrm{ml}$ of medium in polyethylene vials shaken $80 / \mathrm{min}$ at $37^{\circ} \mathrm{C}$. After two hours of incubation two aliquots $(0.1 \mathrm{ml})$ of the medium were removed for glycerol determinations (Wieland [24] as modified by Chernick [5]). Glycerol production ( $\mu$ moles per $10^{7}$ cells) was calculated as the mean of quadruplicate incubations corrected for the non-incubated controls. The glycerol production was linear for at least two hours incubation [26].

Adipose tissue was homogenized in glass and the lipids extracted according to Dole [6]. The lipid content of adipose tissue was determined gravimetrically. Agents added in vitro were: Pig insulin (25 units $/ \mathrm{mg}$ ) (gift from Novo Research Institute, glucagon content less than 0.2 p.p.m.), L-noradrenaline bitartrate (NA) (supplied by Astra, Södertälje, Sweden), 1-isopropylnoradrenaline-d-bitartrate dehydrate (ISNA) (supplied by Dr F-P Luduena from Sterling Wintrop Research Institute).

From a number of earlier experiments it was ascertained that the two lipolytic agents would be used in a concentration $\left(2 \times 10^{-5} \mathrm{M}\right)$ which induced nearly maximal lipolysis. The concentration of insulin $(100 \mu \mathrm{U} / \mathrm{ml})$ was chosen firstly because it was within the normal physiological range; secondly be- cause we observed that a further rise in insulin concentration was not concomitant with substantial increase in the antilipolytic effect (Gries et al. [8]).

\section{Cell Size Determination}

Two fat specimens weighing about $20-30 \mathrm{mg}$ each were used for the determination of the cell diameter according to the procedure developed by Sjöström et al. [20]. The diameters of 100 cells were measured with a calibrated eye-piece in a Zeiss photomicroscope. Observer bias appeared to be insignificant. The mean cell volume was calculated from the average diameter and the S.D. of the diameter according to the formula suggested by Hirsch and Gallian [10]. The number of fat cells incubated was calculated using the mean cellular triglyceride content and the total triglyceride content of the fat portions.

\section{Calculations}

The percentage changes in the basal lipolysis (Basal) induced by insulin $(100 \mu \mathrm{U} / \mathrm{ml})$ was calculated as follows:

$$
\frac{\text { Basal - Insulin }}{\text { Basal }} \times 100=\text { per cent decrease. }
$$

In order to evaluate the inhibitory effect of insulin on the catecholamine induced increment in lipolysis, the noradrenaline effect in the insulin containing medium $[(\mathrm{CA}+$ insulin $)-$ (insulin $)]$ was compared with the noradrenaline effect in insulin-free medium [(CA) - (Basal)]. These values were obtained by incubation of adipose tissue in four different types of incubation medium with additions of agents as given in the formula. The statistical calculations were performed according to Snedecor [22].

\section{Results}

From Fig. 1 it is seen that the rate of the basal lipolysis, i.e. the release of glycerol from $10^{7}$ fat cells incubated for two hours in Krebs-Henseleit bicarbonate buffer with $4 \%$ of albumin was significantly correlated with mean volume of the fat cells $(r=+0.77$; $p<0.01)$. From the regression line it appears that the largest fat cells $\left(1500 \mathrm{~mm}^{3} \times 10^{-6}\right)$ released glycerol almost six times as fast as the smallest fat cells $\left.500 \mathrm{~mm}^{3} \times 10^{-6}\right)$. In the Figs. $2 \mathrm{a}$ and $\mathrm{b}$ is presented the rate of glycerol release (per $10^{7}$ cells/2 hours) into incubation medium containing either noradrenaline (NA) $\left(2 \times 10^{-5} \mathrm{M}\right)$ or the equimolar concentration of isopropylnoradrenaline (ISNA) alone, or any of these agents plus insulin $(100 \mu \mathrm{U} / \mathrm{ml})$. The glycerol release was significantly $(p<0.001)$ correlated with the mean 
volume of the fat cells in each of the four types of incubation medium. The correlation coefficients varied between $0.74-0.81$. The slopes $(p<0.05)$ as well as the elevations $(p<0.01)$ of the two regression lines, CA with and without insulin respectively, were statistically different both in the noradrenaline and the isopropyl-noradrenaline experiments. It is seen from the regression lines that the addition of insulin $(100 \mu \mathrm{U} / \mathrm{ml})$ resulted in a significant decrease in the slope of the line.

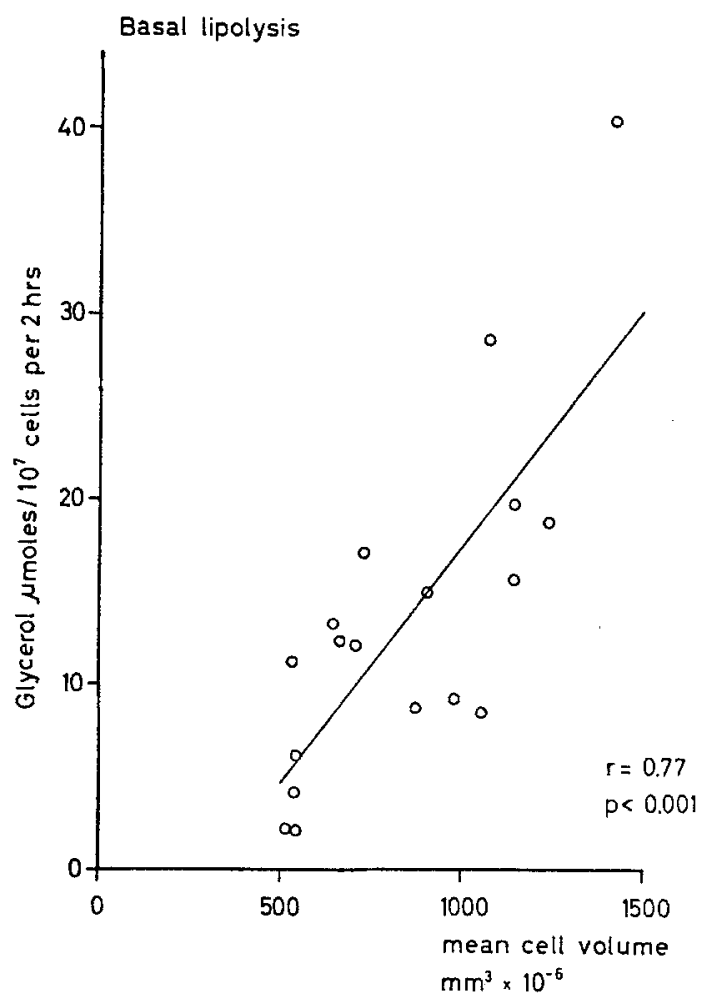

Fig. 1. Relation between the mean cell volume of human fat cells and the basal release of glycerol (umoles) in vitro. $10^{7}$ fat cells were incubated for two hours in $1 \mathrm{ml}$ of KrebsHenseleit bicarbonate buffer containing $4 \%$ bovine albumin. No glucose added

The enlarged fat cells liberated glycerol twice as rapidly as the small fat cells, when lipolysis was expressed per gram triglycerides of the fat cells. Even if so calculated the lipolytic responses to the $\mathrm{CA}$ are more pronounced in the larger fat cells.

This indicates that the insulin effect was more pronounced in the larger fat cells. The effect of insulin on the basal lipolysis was also more marked in the large fat cells (Fig. 3). A strong, positive relationship $(r:+0.63, p<0.005)$ was observed between the effect of insulin (when inhibition was expressed as percentage of the basal lipolysis) and the mean volume of the fat cells. This raised the question as to whether or not the decrease in glycerol release from adipose tissue exposed to insulin and catecholamines might be due only to an insulin effect on basal lipolysis.

Therefore, the catecholamine effect in insulin containing medium $[(\mathrm{CA})+$ insulin) - (insulin) $]$ was compared with the effect in insulin-free medium [(CA) - (Basal)]. In Figs. $4 a$ and $b$, is shown that the effect of NA was inhibited by insulin to almost the same degree in the larger fat cells, when expressed in absolute values, whereas the percentage decrease seemed to be more pronounced in the smaller fat cells. Thus, the effect of insulin on the basal lipolysis was more pronounced than the inhibitory effect of insulin on the NA induced lipolysis. In the ISNA experiment (Fig. 4b) it is even more apparent that insulin had little if any effect on the induced lipolysis. Neither the slopes nor the intercepts were significantly different.

In Table 2 are presented the changes in the body weight, the mean fat cell size and the rates of lipolysis occurring several months after the intestinal shunt operation performed in five obese subjects. These patients had an average body weight of $235 \%$ of the ideal before the operation. At the time of the second adipose tissue biopsy their mean body weights corresponded to about $162 \%$ of the ideal. During the same time the mean cell size had decreased from $1065 \pm 113$ to $528 \pm 132 \mathrm{~mm}^{3} \times 10^{-6}$. From Table 2 it is seen that the rate of lipolysis was less rapid on the second occasion under all incubation conditions of the adipose tissue. The mean percentage decrease in lipolysis induced by insulin was $61 \%$ before and $38 \%$ after the operation.

\section{Discussion}

In agreement with previous investigation $[9,13$, $15,26]$, the present results show that the lipolysis of human subcutaneous adipose tissue is closely related to the size of the fat cells. Although the antilipolytic effect of insulin $(100 \mu \mathrm{U} / \mathrm{ml})$ seems to be cell sizedependent, this relationship may be more apparent than real. In the presence of $100 \mu \mathrm{U} / \mathrm{ml}$ of insulin, the glycerol production by adipose tissue was reduced to approximately the same figure irrespective of the mean size of the fat cells (Table 2). Since the basal rate of lipolysis in the absence of insulin was strongly and positively correlated with the mean cell size the antilipolytic effect of insulin will also be cell sizedependent. Of even greater importance was the observation that the antilipolytic effect of insulin was correlated with the mean fat cell size, even when the antilipolytic effect was calculated as the relative decrease (Fig. 3) in the basal lipolysis. 
Table 2. Effects of body weight reduction on the mean fat cell size and the rate of lipolysis in the basal incubation medium, in the presence of insulin $(100 \mu \mathrm{U} / \mathrm{ml})$, noradrenaline $(N A)\left(2 \times 10^{-5} \mathrm{M}\right)$, isopropylnoradrenaline $(\mathrm{ISNA})\left(2 \times 10^{-5} \mathrm{M}\right)$ and with $N A$ and ISNA plus insulin

\begin{tabular}{|c|c|c|c|c|c|c|c|c|}
\hline \multirow{2}{*}{$\begin{array}{l}\text { Pat. } \\
\text { no. }\end{array}$} & \multirow{2}{*}{$\begin{array}{l}\text { B.wt. } \\
\text { of of ideal }\end{array}$} & \multirow{2}{*}{$\begin{array}{l}\text { Mean fat } \\
\text { cell size } \\
\mathrm{mm}^{3} \times 10^{-6}\end{array}$} & \multirow[t]{2}{*}{ Basal } & \multicolumn{5}{|c|}{ Glycerol release ( $\mu$ moles $/ 10^{7}$ cells $/ 2 \mathrm{hrs}$ ) } \\
\hline & & & & Insulin & NA & ISNA & NA+ insulin & $\begin{array}{l}\text { ISNA+ in- } \\
\text { sulin }\end{array}$ \\
\hline 1 & $\begin{array}{l}241 \\
133\end{array}$ & $\begin{array}{r}1423 \\
516\end{array}$ & $\begin{array}{r}40.62 \\
9.79\end{array}$ & $\begin{array}{l}9.29 \\
6.12\end{array}$ & $\begin{array}{l}57.66 \\
15.22\end{array}$ & $\begin{array}{l}59.73 \\
11.36\end{array}$ & $\begin{array}{r}33.56 \\
9.18\end{array}$ & $\begin{array}{r}33.22 \\
8.40\end{array}$ \\
\hline 2 & $\begin{array}{l}202 \\
135\end{array}$ & $\begin{array}{l}727 \\
238\end{array}$ & $\begin{array}{r}17.25 \\
4.14\end{array}$ & $\begin{array}{l}4.22 \\
3.53\end{array}$ & $\begin{array}{r}36.18 \\
8.80\end{array}$ & $\begin{array}{r}37.16 \\
7.63\end{array}$ & $\begin{array}{r}21.96 \\
6.01\end{array}$ & $\begin{array}{r}19.31 \\
5.40\end{array}$ \\
\hline 3 & $\begin{array}{l}192 \\
131\end{array}$ & $\begin{array}{l}980 \\
355\end{array}$ & $\begin{array}{r}15.06 \\
6.39\end{array}$ & $\begin{array}{l}5.51 \\
2.40\end{array}$ & $\begin{array}{l}29.84 \\
15.05\end{array}$ & $\begin{array}{l}32.47 \\
15.86\end{array}$ & $\begin{array}{r}26.74 \\
9.47\end{array}$ & $\begin{array}{r}23.26 \\
9.23\end{array}$ \\
\hline 4 & $\begin{array}{l}262 \\
203\end{array}$ & $\begin{array}{r}1052 \\
521\end{array}$ & $\begin{array}{l}8.55 \\
5.28\end{array}$ & $\begin{array}{l}5.66 \\
3.77\end{array}$ & $\begin{array}{r}17.71 \\
9.15\end{array}$ & $\begin{array}{r}19.64 \\
8.45\end{array}$ & $\begin{array}{r}14.82 \\
5.43\end{array}$ & $\begin{array}{r}13.98 \\
5.81\end{array}$ \\
\hline 5 & $\begin{array}{l}270 \\
207\end{array}$ & $\begin{array}{l}1144 \\
1010\end{array}$ & $\begin{array}{l}19.83 \\
14.13\end{array}$ & $\begin{array}{l}8.44 \\
7.40\end{array}$ & $\begin{array}{l}40.43 \\
36.32\end{array}$ & $\begin{array}{l}36.38 \\
30.43\end{array}$ & $\begin{array}{l}22.03 \\
21.47\end{array}$ & $\begin{array}{l}22.73 \\
16.96\end{array}$ \\
\hline $\bar{X}_{1}$ & 234.6 & 1065 & 20.3 & 6.6 & 36.4 & 37.1 & 23.8 & 22.5 \\
\hline$\overline{\mathbf{X}}_{2}$ & 161.8 & 528 & 7.9 & 4.8 & 16.9 & 14.8 & 10.3 & 9.2 \\
\hline $\mathrm{p}$ & $<0.002$ & $<0.002$ & $<0.07$ & $<0.02$ & $<0.05$ & $<0.04$ & $<0.03$ & $<0.002$ \\
\hline
\end{tabular}

Statistical significance calculated from paired observations, Snedecor (1957).

$\bar{X}_{1}$ and $\bar{X}_{2}$ denote the mean values before and after jejunoileostomy.

Lipolytic effect of noradrenaline

with and without insulin present.

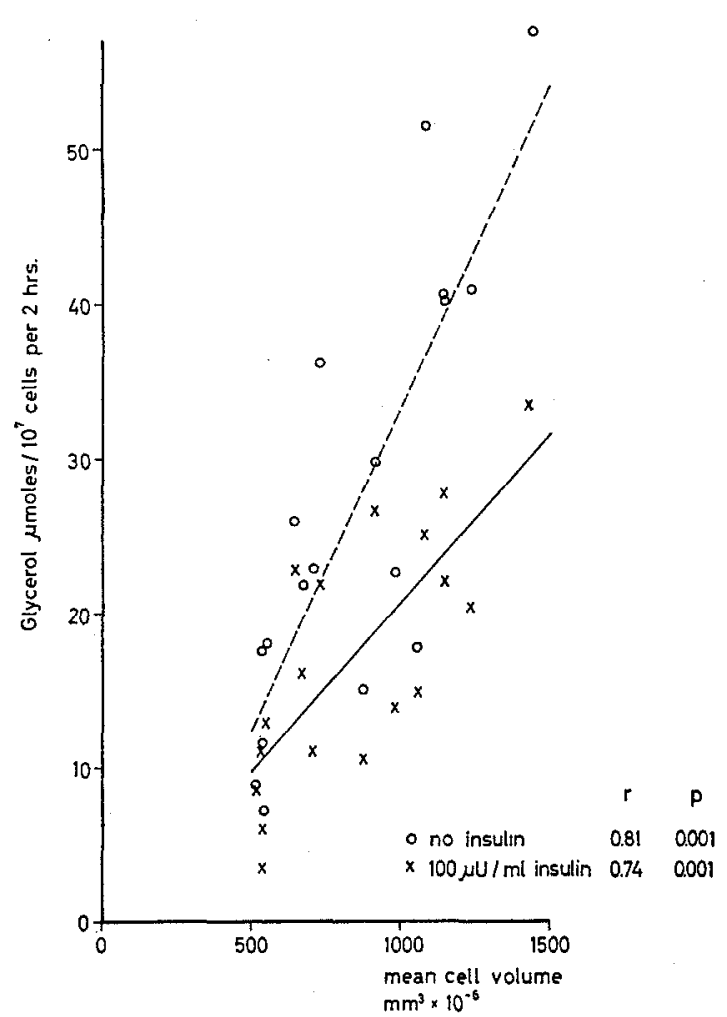

Lipolytic effect of isopropylnoradrenaline with and without insulin present.

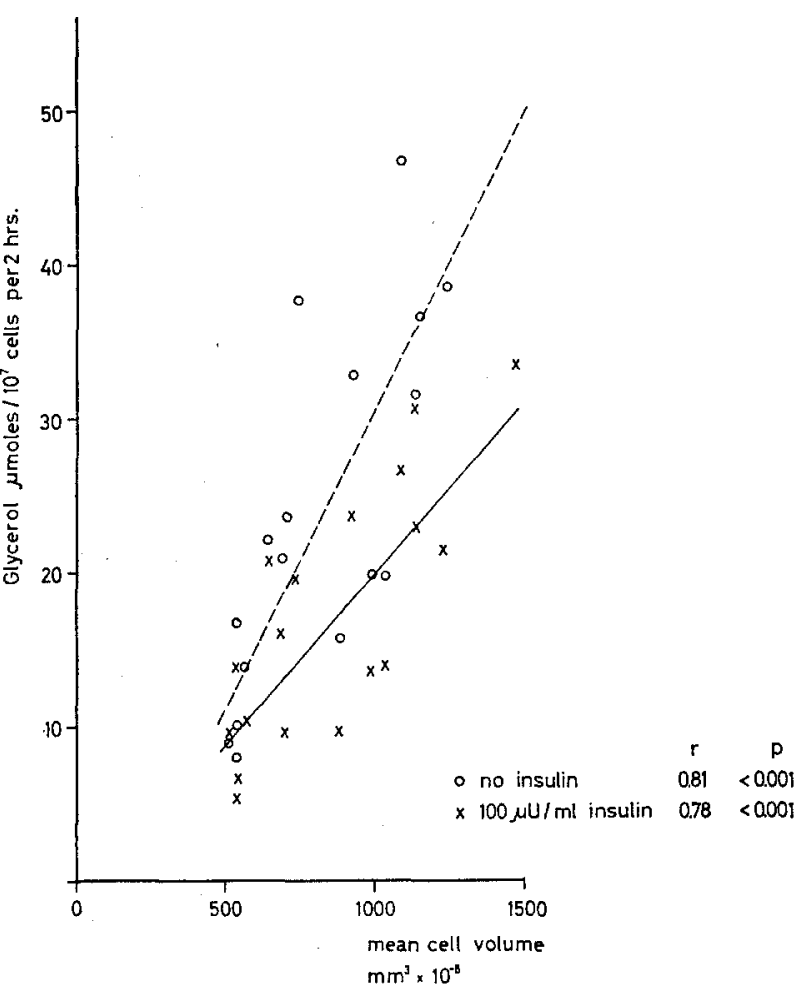

b

Fig. $2 a-b$. Relation between the mean volume of human fat cells and their release of glycerol (umoles) in vitro. $10^{7}$ fat cells were incubated for two hours in the presence of [2a] noradrenaline (NA) $\left(2 \times 10^{-5} \mathrm{M}\right)$ alone and plus insulin $(100 \mu \mathrm{U} / \mathrm{ml})$ and [2 b] isopropyl-noradrenaline (ISNA) $\left(2 \times 10^{-5} \mathrm{M}\right)$ alone and plus insulin $(100 \mu \mathrm{U} / \mathrm{ml})$. Incubation medium see legends to Fig. 1 


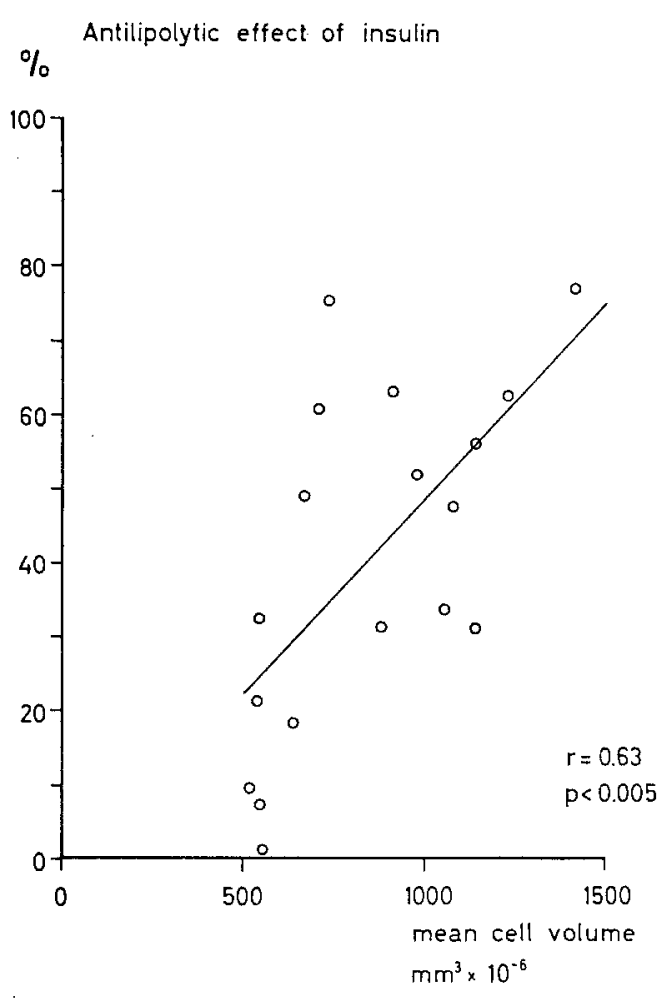

Fig. 3. Relation between the mean volume of human fat cells and the percentage decrease in basal glycerol release induced by insulin $(100 \mu \mathrm{U} / \mathrm{ml})$ when basal lipolysis equals 100\%. Incubation conditions see legends to Fig. 1

Lipolytic effect of noradrenaline $(\Delta)$

with and without insulin $(100 \mu \mathrm{U})$ present.

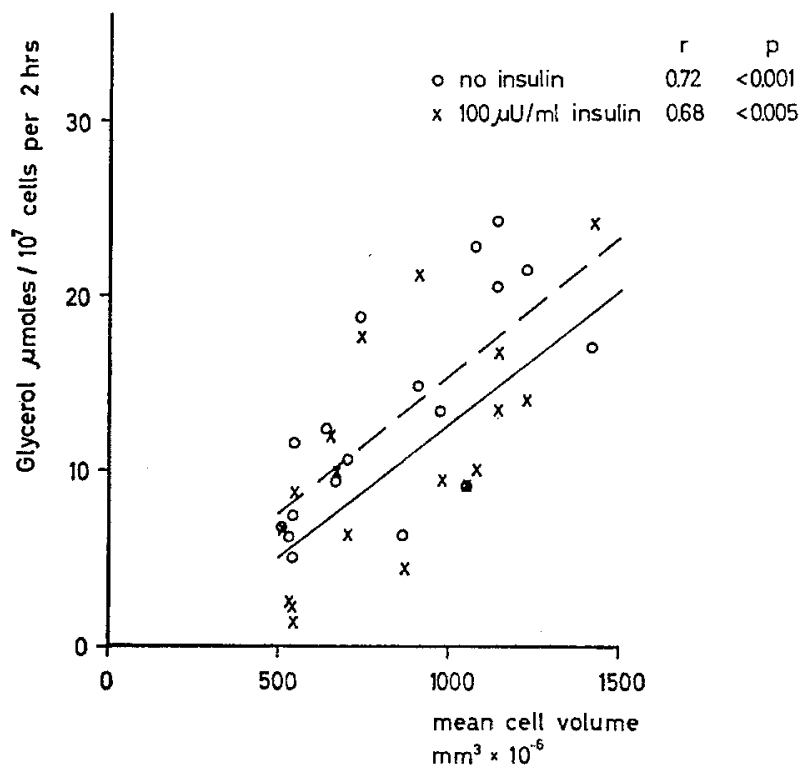

In this context it is important to understand that the positive relationship between the different metabolic parameters is equally well demonstrated when the fat cells of different size are obtained from one individual or when they are obtained from subjects with different amounts of body fat and size of fat cells. Thus, our findings are in close agreements with those of Jacobsson and Smith [13] showing that the larger adipose cells are at least as sensitive to the antilipolytic effect of insulin as the smaller fat cells.

In the present investigation the antilipolytic effect of insulin was easily observed on glycerol formation by adipose tissue with stimulated lipolysis. On the other hand, no apparent insulin effect was shown on the increment in lipolysis produced by either noradrenaline or isopropylnoradrenaline. We have, in separate experiments which are not included here, observed that this holds true for a wide range in concentrations of the catecholamines. The only exception seems to be lipolysis produced by high concentrations of noradrenaline, which is, in some experiments potentiated by insulin. Our findings differ substantially from those of several authors who studied the concentration of cyclic $3^{1} \cdot 5^{1}$-adenosine-mono-phosphate (cyclic AMP) under similar experimental conditions $[2,3$,

Lipolytic effect of ISNA $(\Delta)$

with and without insulin present
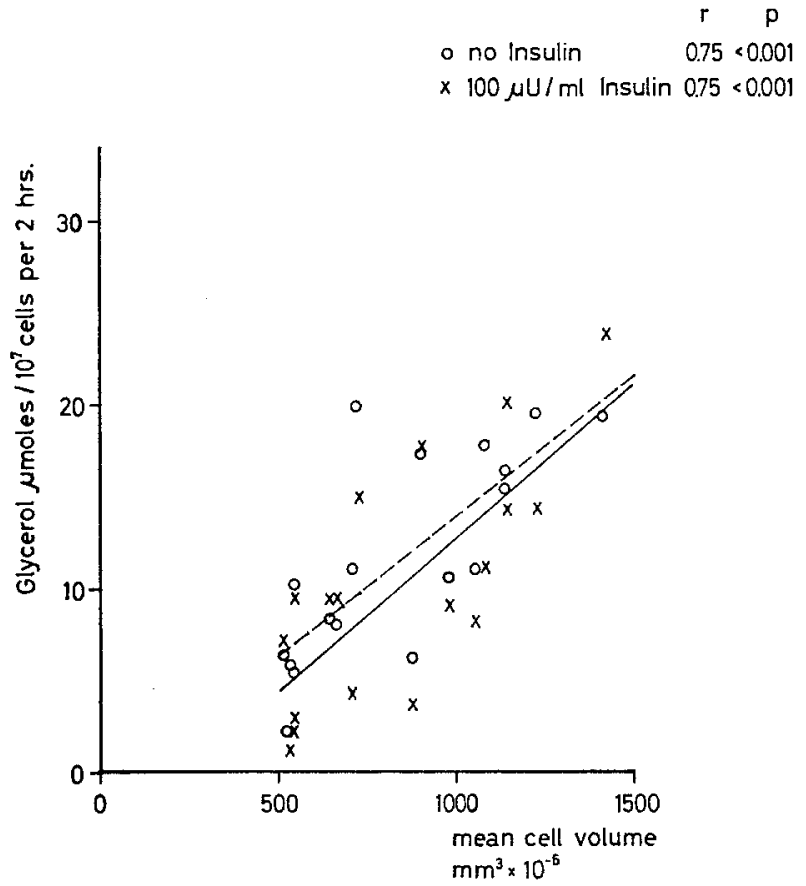

Fig. $4 \mathrm{a}-\mathrm{b}$. Relation between the mean volume of human fat cells and the lipolytic effect of noradrenaline (NA) $\left(2 \times 10^{-5} \mathrm{M}\right)$ (4 a) or isopropyl-noradrenaline (ISNA) $\left.2 \times 10^{-5} \mathrm{M}\right)(4 \mathrm{~b})$ alone and in the presence of insulin $(100 \mu \mathrm{U} / \mathrm{ml})$. The lipolytic effect of the catecholamines was calculated as the increase in the rate of glycerol release above basal. See "Calculations". Incubation conditions see legends to Fig. 1 
$16,17]$. In these experiments insulin lowered the concentration of cyclic AMP in rat adipose tissue only when incubated with lipolytic hormones and not in the absence of these hormones. It is possible that the use of the incomplete cyclic AMP phosphodiesterase inhibitor theophylline in those experiments, but not in our own, could explain the difference between the results. If this explanation is correct it seems probable that insulin lowers the cyclic AMP production by increasing the cyclic AMP phosphodiesterase activity.

In other investigations of human adipose tissue [7, $19,21]$ it has been demonstrated that the effect of insulin on glucose oxidation is less rapid in the large fat cells. Bearing in mind the more pronounced antilipolytic effect of insulin in large adipocytes, it seems unlikely that diminished insulin binding by the fat cell would explain the low insulin response (glucose oxidation) in the large fat cells. Direct proof of normal binding capacities and affinities for insulin in large fat cells of the rat have also been presented by Livingston et al. [16].

Finally, the present data also confirm previous observations [14] showing that a substantial loss of body weight induced by caloric restriction resulted in a significant decrease in the size of the subcutaneous fat cells. All the lipolytic parameters, including the antilipolytic effect of insulin, were changed roughly in proportion to the changes in the fat cell size.

\section{References}

1. Arner, P., Arner, O., Östman, J.: The effect of local anaesthetic agents on lipolysis by human adipose tissue. Life Sci. 13, $161-169$ (1973)

2. Buchwald, H., Varco, R. L.: A bypass operation for obese hyperlipidemic patients. Surgery 70, 62-70 (1971)

3. Butcher, R. W., Sneyd, J. G. T., Park, C. R., Sutherland, E. W.: Effect of insulin on adenosine 3.5-monophosphate in the rat epididymal fat pad. J. biol. Chem. 241, 16511653 (1966)

4. Butcher, R. W., Baird, C. E., Sutherland, E. W.: Effect of lipolytic and antilipolytic substances on adenosine 3.5monophosphate levels in isolated fat cells. J. biol. Chem. 243, 1705-1712 (1968)

5. Chernick, S. S.: Determination of glycerol in acyl glycerols. In: Loewenstein, J. M. (Ed.): Methods in Enzymology, Lipids, vol. 4, p. 627. New York \& London: Acad. Press 1969

6. Dole, V. P.: A relation between non-esterified fatty acids in plasma and the metabolism of glucose. J. clin. Invest. 35, 150-154 (1956)

7. Englhardt, A., Kasperel, R., Liebermeister, H., Jahnke, K.: Studies on glucose utilization and insulin responsiveness of human subcutancous adipose tissue in obese and nonobese subjects. Horm. Metab. Res. 3, 266-272 (1971)

8. Gries, F. A., Berger, M., Oberdisse, K.: Untersuchungen zum antilipolytischen Effekt des Insulins am menschlichen Fettgewebe in vitro. Diabetologia 4, 262-267 (1968)
9. Gries, F. A., Berger, M., Neumann, M., Preiss, H., Liebermeister, H., Hesse-Wortmann, C., Jahnke, K.: Untersuchungen zum antilipolytischen Effekt des Insulins am menschlichen Fettgewebe in vitro. Diabetologia 8, 75-83 (1972)

10. Hirsch, J., Gallian, E.: Methods for the determination of adipose cell size and cell number in man and animals. J. Lipid Res. 9, 110 - 119 (1968)

11. Hirsch, J., Knittle, J. L.: Cellularity of obese and nonobese human adipose tissue. Fed. Proc. 29, 1516-1521 (1971)

12. Ikkos, D., Luft, R.: On the intravenous glucose tolerance test. Acta endocr. (Kbh.) 25, 312-334 (1952)

13. Jacobsson, B., Smith, U.: Effect of cell size on lipolysis and antilipolytic action of insulin in human fat cells. J. Lipid Res. 13, 651-656 (1972)

14. Knittle, J. L., Ginsberg-Fellner, F.: Effect of weight reduction on in vitro adipose tissue lipolysis and cellularity in obese adolescents and adults. Diabetes 21, 754-766 (1972)

15. Lisch, H.-J., Sailer, S., Sandhofer, F., Braunsteiner, H.: Untersuchungen an isolierten menschlichen Fettzellen verschiedener Fettgewebsregionen. II. Beziehungen zwischen Zellvolumen und basaler Lipolyse. Klin. Wschr. 22, 15531356 (1970)

16. Livingston, J. N., Cuatrecasas, P., Lockwood, D. H.: Insulin insensitivity of large fat cells. Science 177, 175177 (1972)

17. Manganiello, V. C., Murad, F., Vaughan, M.: Effects of lipolytic and antilipolytic agents on cyclic 3.5-adenosine monophosphate in fat cells. J. biol. Chem. 241, 21952202 (1971)

18. Park, C. R., Sneyd, J. G. T., Corbin, J. D., Jefferson, L. S., Exton, J. H.: Role of cyclic adenylate in the actions of insulin. In: Proceedings 6th Congress Int. Diabetes Fed. Östman, J. (Ed.): pp. 5-15. Amsterdam: Excerpta Medica 1969

19. Salans, L. B., Knittle, J. L., Hirsch, J.: The role of adipose cell size and adipose tissue insulin sensitivity in the carbohydrate intolerance of human obesity. J. clin. Invest. 47, 153-165 (1968)

20. Sjöström, L., Björntorp, P., Vrána, J.: Microscopic fat cell size measurements on frozen-cut adipose tissue in comparison with automatic determinations of osmiumfixed fat cells. J. Lipid Res. 12, $521-530$ (1971)

21. Smith, U.: Effect of cell size on lipid synthesis by human adipose tissue in vitro. J. Lipid Res. 12, 65-70 (1971)

22. Snedecor, G. W.: Statistical methods. Iowa, Iowa State: College Press 1957

23. Statist. Bull. Metrop. Life Insur. Co.: 40, 1 - 4 (1959)

24. Wieland, O.: Eine enzymatische Methode zur Bestimmung von Glycerin. Biochem. Z. 329, 313-319 (1957)

25. Östman, J.: A procedure for in vitro studies on fatty acid metabolism by human subcutaneous adipose tissue. Acta med. scand. 177, 183-197 (1965)

26. Östman, J., Backman, L., Hallberg, D.: Cell size and lipolysis by human subcutaneous adipose tissue. Acta med. scand. 193, 469-475 (1973)
J. Östman, M. D.
Assoc. Prof.
Karolinska Institutet
Dept. of Medicine
Huddinge Univ. Hospital
S-141 86 Huddinge
Sweden 